\title{
Umbilical Cord Tissue-derived Mesenchymal Stem Cells Should be Considered as Adjuvant Therapy for COVID-19 Treatment: An Opinion from Pooled Clinical Evidence
}

\author{
Bich Ngoc Vu ${ }^{(\bullet}$, Van Phuc Pham* ${ }^{*}$
}

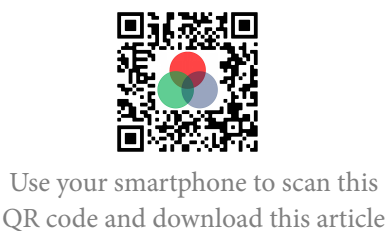

\begin{abstract}
In 2020, we suggested that umbilical cord-derived mesenchymal stem cell (UC-MSC) transplantation can significantly improve coronavirus disease 2019 (COVID-19) symptoms based on evidential relations (10.4252/wjsc.v12.i8.721). One year later, this review aims to summarize and update the clinical evidence regarding UC-MSC usage in COVID-19 treatment. The publications on applications of UC-MSCs were searched in the PubMed, Web of Science, and Google scholar databases with the keywords "umbilical cord-derived mesenchymal stem cells" and "COVID-19". All publications about clinical studies, from case reports to randomized controlled trials (RCTs), were used as clinical evidence in this review. The results showed 16 publications (4 randomized clinical trials, 3 pilot studies/phase 1 clinical trials, 3 case series reports, and 6 case reports) with a total of 395 COVID-19 patients that were provided with UC-MSC transplantation. All publications demonstrated that UC-MSC transplantation is safe, well tolerated, improved COVID-19 symptoms, and significantly decreased mortality. These findings support our suggestion for the usage of off-the-shelf UC-MSCs for COVID-19 as an adjuvant therapy.

Key words: Covid-19, Mesenchymal stem cell, SARS-CoV-2, Stem cells, Umbilical cord derived mesenchymal stem cell
\end{abstract}

Stem Cell Institute, University of Science, Vietnam National University Ho Chi Minh City, Viet Nam

\section{Correspondence}

Van Phuc Pham, Stem Cell Institute, University of Science, Vietnam National University Ho Chi Minh City, Viet Nam

Email: phucpham@sci.edu.vn

History

- Received: Aug 09, 2021

- Accepted: Sep 22, 2021

- Published: Sep 30, 2021

DOI : 10.15419/bmrat.v8i9.694

\section{Check for updates}

\section{Copyright}

(c) Biomedpress. This is an openaccess article distributed under the terms of the Creative Commons Attribution 4.0 International license.

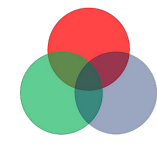

BioMedPress

The Open Access Publisher

\section{INTRODUCTION}

Coronavirus disease 2019 (COVID-19) is a new pandemic that has affected hundreds of millions of people worldwide. As of August 2021, more than 200 million people were confirmed as positive for severe acute respiratory syndrome coronavirus 2 (SARS-CoV-2), and more than 4 million people had died due to the disease this virus (COVID-19) caused $^{\mathbf{1}}$. Affected patients are characterized by typical pneumonic symptoms such as fever, cough, and shortness of breath. COVID-19 patients with comorbidities tend to be more affected by this disease and have a higher mortality rate $\mathrm{r}^{2-4}$ than children and young people.

The current therapies for COVID-19 treatment are antiviral drugs, dexamethasone, anti-inflammatory drugs, convalescent plasma therapy, and even medicinal plants ${ }^{5-8}$. Indeed, most COVID-19 patients are now treated symptomatically. Other methods related to mechanical ventilation are also used in case of severe respiratory distress in some patients ${ }^{\mathbf{9} 10}$. Currently, many therapies are being developed to effectively treat and manage COVID-19, one of which is stem cell therapy.

Based on the pathophysiology of COVID-19 and biological characteristics of mesenchymal stem cells
(MSCs), these cells have been used at an early clinical stage in some clinical trials to treat severe and critical COVID-19 patients ${ }^{11}$. MSCs are the most frequently isolated adult stem cells from various tissues in the body. In contrast to embryonic and other adult stem cells, MSCs are easily isolated and can be expanded substantially with various automatic cell culture factory systems; therefore, MSCs based on stem cell drugs (off-the-shelf stem cells) have been developed and commercialized since $2012^{12,13}$. MSCs can participate in disease treatment and management through at least three mechanisms: immune modulation, multilineage differentiation, and regeneration triggering through their cytokines ${ }^{\mathbf{1 4}}$. Hence, MSCs are clinically used to treat various diseases, from autoimmune conditions to vascular regeneration. More interestingly, in contrast to other stem cells, MSCs express HLA to only a small degree and have low immunogenicity; therefore, they can be used in allogenic transplantation without HLA matching ${ }^{15,16}$.

Although MSCs can be isolated from various tissues, such as bone marrow, adipose tissue, peripheral blood, the potency of MSCs from different sources has been found to vary ${ }^{17-19}$. In comparison to bone marrow-MSCs (BM-MSCs) and adi- 
pose tissue-derived MSCs (ADSCs), umbilical cordderived MSCs (UC-MSCs) display the strongest immunomodulation ${ }^{17}$. Based on early evidence of the usage of MSCs in COVID-19 treatment ${ }^{11}$ and from published clinical usages of UC-MSCs in chronic obstructive pulmonary disease (COPD) ${ }^{20}$ and septic illnesses $^{21-23}$, we have suggested the usage of off-theshelf UC-MSC products for COVID-19 ${ }^{14}$. This review aims to outline the opinions based on pooled published clinical evidence regarding UC-MSC transplantation in COVID-19 patients.

\section{PUBLICATIONS ON UC-MSC TRANSPLANTATION FOR COVID-19 PATIENTS}

Sixteen publications involved the use of UCMSC transplantation to treat COVID-19 patients, including 4 randomized clinical trials (110 patients), 3 pilot studies/phase 1 clinical trials (52 patients), 3 case series reports (227 patients), and 6 case reports (6 patients). Thus, to date, 395 COVID-19 patients have been infused with UC-MSCs. In addition, there are eight publications from China, two from Turkey, and one from Iran, the Philippines, Brazil, Indonesia, the USA, and Italy (Table 1,Table 2).

Table 1: Publications on UC-MSC transplantation for COVID-19 patients

\begin{tabular}{lccc}
\hline $\begin{array}{l}\text { Kinds of } \\
\text { clinical study }\end{array}$ & $\begin{array}{c}\text { No } \\
\text { of } \\
\text { studies }\end{array}$ & $\begin{array}{c}\text { Total patients } \\
\text { treated with } \\
\text { UC-MSCs }\end{array}$ & $\begin{array}{c}\text { Adverse } \\
\text { effects }\end{array}$ \\
\hline $\begin{array}{l}\text { Randomized } \\
\text { clinical trial }\end{array}$ & 4 & 110 & 0 \\
$\begin{array}{l}\text { Pilot } \\
\text { study/Phase } \\
1 \text { clinical }\end{array}$ & 3 & 52 & 0 \\
trial & & 227 & 0 \\
Case series & 3 & 6 & 0 \\
report & & 395 & 0 \\
Case report & 6 & 16 &
\end{tabular}


Table 2: Summary for published clinical studies of UC-MSC transplantation for Covid-19

\begin{tabular}{|c|c|c|c|c|c|c|c|c|}
\hline No & Year & Kind of study & No of patients & $\begin{array}{l}\text { Follow- } \\
\text { up time }\end{array}$ & Interventions & Efficacy & Country & Ref \\
\hline 1 & 2021 & $\begin{array}{l}\text { Single center } \\
\text { open label, } \\
\text { individually } \\
\text { randomized, } \\
\text { standard } \\
\text { treatment } \\
\text { controlled trial }\end{array}$ & $\begin{array}{l}12 \text { patients in } \\
\text { UC-MSC, } 29 \text { in } \\
\text { control }\end{array}$ & $\begin{array}{l}28 \text { days } \\
\text { and } \\
\text { follow- } \\
\text { up to } 3 \\
\text { months } \\
\text { for lung } \\
\text { function } \\
\text { recovery }\end{array}$ & $\begin{array}{l}2 \times 10^{6} \text { fresh UC-MSCs/kg, sus- } \\
\text { pended in } 100 \mathrm{~mL} \text { of normal } \\
\text { saline and infusion in } 1 \text { hour }\end{array}$ & $\begin{array}{l}100 \%(12 / 12) \text { patients in the treatment group im- } \\
\text { proved, discharged, no invasive ventilation, } 0 \% \text { mor- } \\
\text { tality; } 4 \text { patients in the control group went to invasive } \\
\text { ventilartion, } 3 \text { of them died, } 10.34 \% \text { mortality; CRP and } \\
\text { IL- } 6 \text { clearly reduced in the treatment group from day } 3 \text {; } \\
\text { chest CT scanning showed that absorption of lung in- } \\
\text { flammation was faster in the treatment group compared } \\
\text { to the control group. }\end{array}$ & China & 5 \\
\hline 2 & 2021 & $\begin{array}{l}\text { Pilot study } \\
\text { with control, } \\
\text { not randomly }\end{array}$ & $\begin{array}{l}12 \text { patients in } \\
\text { treatment; and } \\
12 \text { patients in } \\
\text { conventional } \\
\text { therapy (alone) }\end{array}$ & $\begin{array}{l}16 \text { days } \\
\text { for effi- } \\
\text { cacy and } \\
60 \text { days } \\
\text { for safety }\end{array}$ & $\begin{array}{l}10^{6} \mathrm{UC}-\mathrm{MSCs} / \mathrm{kg} \text {; cells sus- } \\
\text { pended in } 100 \mathrm{~mL} \text { of normal } \\
\text { saline, infusion with } 60 \text { drops } \\
\text { per minutes for } 30 \mathrm{~min}\end{array}$ & $\begin{array}{l}1 / 12 \text { patient in treatment died (not related to MSC in- } \\
\text { fusion); the biomarkers of CRP, IL- } 6 \text {, TNF-alpha were } \\
\text { no significantly after UC-MSC infusion; } 11 / 12 \text { patients } \\
\text { with MSCs improved the CT images for lung imflam- } \\
\text { mation. }\end{array}$ & China & 24 \\
\hline 3 & 2021 & Case series & $\begin{array}{l}210 \text { patients } \\
(99 \text { patients } \\
\text { with intubate, } \\
\text { and } 111 \\
\text { unintubated) }\end{array}$ & $2-3$ wks & $\begin{array}{l}1-2 \times 10^{6} \mathrm{UC}-\mathrm{MSCs} / \mathrm{kg} \text {, sus- } \\
\text { pended in } 100 \mathrm{~mL} \text { of normal } \\
\text { saline, infused with rates of } 2 \\
\mathrm{~mL} / \mathrm{min} \text { in } 50-60 \mathrm{~min}\end{array}$ & $\begin{array}{l}\mathrm{SpO}_{2} \text { improved after transplantation in both groups of } \\
\text { intubated and unintubated. But there was not statsiti- } \\
\text { cally sigificant between } 2 \text { groups; } 52.5 \% \text { (52/99) (crit- } \\
\text { ical illness); } 86 / 111 \text { ( } 77.5 \%) \text { (serve illness) were good } \\
\text { progress/discharged from ICU; } 47 / 99 \text { ( } 47.5 \% \text { critical), } \\
22.5 \% \text { ( } 25 / 111 \text { severe) died. }\end{array}$ & Turkey & 25 \\
\hline 4 & 2021 & Case report & $\begin{array}{l}1 \text { patient ( } 66 \\
\text { years old), } \\
\text { critically ill } \\
\text { patient }\end{array}$ & 28 days & $\begin{array}{l}10^{6} \text { fresh UC-MSCs } / \mathrm{kg}, 3 \text { times } \\
\text { of infusions per round for } 2 \\
\text { rounds; } 40 \text { drops } / \text { min for } 40-50 \\
\text { min }\end{array}$ & $\begin{array}{l}\text { After } 2^{\text {nd }} \text { round of UCMSC, patients stayed in critical } \\
\text { care unit (CCU) for } 20 \text { days; most of vital signs and } \\
\text { clinical lab recovered to normal range; IL- } 6 \text { significant } \\
\text { reduced after UC-MSC transplantation. }\end{array}$ & China & 26 \\
\hline
\end{tabular}




\begin{tabular}{|c|c|c|c|c|c|c|c|c|}
\hline \multicolumn{9}{|c|}{ Table 2 continued } \\
\hline No & Year & Kind of study & No of patients & $\begin{array}{l}\text { Follow- } \\
\text { up time }\end{array}$ & Interventions & Efficacy & Country & Ref \\
\hline 5 & 2021 & Case report & $\begin{array}{l}1 \text { patient (69 } \\
\text { years old) }\end{array}$ & 8 days & $\begin{array}{l}1.1 \times 10^{6} \text { freshly thawed UC- } \\
\text { MSCs diluted (1:1) with final vol- } \\
\text { ume of } 50 \mathrm{~mL} \text {, intravenous infu- } \\
\text { sion for } 30 \mathrm{~min}\end{array}$ & $\begin{array}{l}\text { Clinical findings showed that improvement of the in- } \\
\text { flammatory, respiratory, thrombotic, and renal param- } \\
\text { eters after } 2 \text { and } 8 \text { days after MSC infusion; IL-1beta, IL- } \\
\text { 1RA, IL- } 6 \text { and TNF-alpha reduced after } 2 \text { days of MSC } \\
\text { infusion. }\end{array}$ & Italy & 27 \\
\hline 6 & 2020 & $\begin{array}{l}\text { Phase } 1 \text {, Clini- } \\
\text { cal trial }\end{array}$ & $\begin{array}{l}18 \text { patients } \\
\text { with } 9 \text { patients } \\
\text { in treatment } \\
\text { group, } 9 \\
\text { patients in control }\end{array}$ & 14 days & $\begin{array}{l}3 \times 10^{7} \text { fresh UCMSCs per each } \\
\text { infusion, for } 3 \text { times on day } 0,3 \\
\text { and } 6 . \text { The total vol in UC-MSCs } \\
\text { was } 60 \mathrm{~mL} \text {. }\end{array}$ & $\begin{array}{l}\text { All patients ( } 18 / 18 \text { patients in both treatment and con- } \\
\text { trol) were discharged from hospital; the duration from } \\
\text { admission to discharge in both groups was same; TNF- } \\
\text { alpha, MCP-1, IP-10, IL-22, IL-1RA, IL-18, and MIP-1 } \\
\text { levels reduced in the treatment group within } 14 \text { days. }\end{array}$ & China & 28 \\
\hline 7 & 2021 & $\begin{array}{l}\text { Randomized, } \\
\text { double-blind, } \\
\text { placebo- } \\
\text { controlled } \\
\text { phase } 2 \text { trial }\end{array}$ & $\begin{array}{l}66 \text { patients } \\
\text { in treatment } \\
\text { group, } \\
35 \text { patients in } \\
\text { placebo }\end{array}$ & 28 days & $\begin{array}{l}4 \times 10^{7} \mathrm{UC}-\mathrm{MSC} / 100 \mathrm{~mL} / \text { dose, } \\
\text { cool preservation }\left(8-12^{\circ} \mathrm{C}\right) \\
\text { shipping less than } 6 \mathrm{~h} \text {; each pa- } \\
\text { tient on day } 0,3 \text {, and } 6 \text { ( } 3 \text { doses })\end{array}$ & $\begin{array}{l}\text { Chest CT examination at baseline, day } 10 \text { and day } 28 \text {; } \\
\text { after } 28 \text { days, solid component lesions were differently } \\
\text { significant in MSC and placebo groups; the decrease in } \\
\text { the ground-glass lesions in MSC group than the placebo } \\
\text { group but not statistically different; there was not sig- } \\
\text { nificant differences in subsets of CD4 } 4^{+} \text {T cells, CD8 }{ }^{+} \text {T } \\
\text { cells, B cells and NK cells; and plasma marker (IL-6, IL- } \\
8 \text {, IFN- } \gamma \text {, IL-1Ra, IL-18, MCP-1, MIP-1 } \alpha \text {, and IP-10) } \\
\text { between } 2 \text { groups. }\end{array}$ & China & 29 \\
\hline 8 & 2021 & $\begin{array}{l}\text { A double- } \\
\text { blind, phase } \\
1 / 2 \mathrm{a} \text { random- } \\
\text { ized controlled } \\
\text { trial }\end{array}$ & $\begin{array}{l}24 \text { patients (12 } \\
\text { in treatment, } 12 \\
\text { in control) }\end{array}$ & 31 days & $\begin{array}{l}80-120 \times 10^{6} \text { freshly thawed UC- } \\
\text { MSCs/infusion, prepared in } 50 \\
\mathrm{~mL} \text {; infusion from } 5 \text { - } 15 \text { mins, at } \\
\text { day } 0 \text { and day } 3 \text { ( } 2 \text { doses) }\end{array}$ & $\begin{array}{l}\text { No serious adverse events (SAEs) were observed in } \\
\text { group of UC-MSC transplantation; Inflammatory cy- } \\
\text { tokines were significantly decreased in UCMSC at day } \\
6 \text {; UC-MSC transplantation significantly improved pa- } \\
\text { tient survival ( } 91 \% \text { versus } 42 \% \text { in control); time to re- } \\
\text { covery is reduced compared to control. }\end{array}$ & USA & 30 \\
\hline
\end{tabular}




\begin{tabular}{|c|c|c|c|c|c|c|c|c|}
\hline \multicolumn{9}{|c|}{ Table 2 continued } \\
\hline No & Year & Kind of study & No of patients & $\begin{array}{l}\text { Follow- } \\
\text { up time }\end{array}$ & Interventions & Efficacy & Country & Ref \\
\hline 9 & 2021 & $\begin{array}{l}\text { A randomized } \\
\text { controlled trial }\end{array}$ & $\begin{array}{l}40 \text { patients }(20 \\
\text { in treatment, } 20 \\
\text { in control) }\end{array}$ & 45 days & $\begin{array}{l}10^{6} \text { fresh UC-MSCs/kg in } 100 \\
\mathrm{~mL} \text { saline }\end{array}$ & $\begin{array}{l}\text { Survival rate in UC-MSC group was } 2.5 \text { times higher } \\
\text { than that in the control; UCMSC administration in- } \\
\text { creased the survival rate by } 4.5 \text { times compared to con- } \\
\text { trols; UCMSC significantly decreased IL- } 6 \text { compared to } \\
\text { control. }\end{array}$ & Indones & 31 \\
\hline 10 & 2021 & Case report & 1 (51 year old) & 120 days & $\begin{array}{l}\text { Three infusions with } 500.000 \\
\text { fresh UC-MSCs/kg each infusion } \\
\text { in combination with } 2 \text { infusions } \\
\text { of } 400 \mathrm{mg} \text { of Tocilizumab. } \\
\text { MSCs were diluted in } 30 \mathrm{~mL} \text { of } \\
\text { saline supplemented with } 20 \% \\
\text { HAS, } 5 \% \text { ACD, infused at } 5 \\
\mathrm{~mL} / \mathrm{min} \text {. }\end{array}$ & $\begin{array}{l}\text { The cretinine, TGO, ferritin, D-dimer, and CRP de- } \\
\text { creased; the increase in absolute number of total lym- } \\
\text { phocytes (CD4, Treg T cells); plasmablasts decrease; } \\
\text { CT image showed ground-glass opacities associated } \\
\text { with crosslinking and subpleural lines, predominantly } \\
\text { peripheral and basal at the beginning of treatment with } \\
\text { an increase in D14, completedly regression in D120. }\end{array}$ & Brazil & 32 \\
\hline 11 & 2020 & Pilot study & $\begin{array}{l}31 \text { patients } \\
\text { (media age: } 70 \\
\text { years) }\end{array}$ & NS & $\begin{array}{l}10^{6} \text { fresh UC-MSCs/kg, sus- } \\
\text { pended in } 100 \mathrm{~mL} \text { normal saline } \\
11 \text { patients with single infusion; } \\
9 \text { patients with } 2 \text { infusions; } 11 \\
\text { patients with } 3 \text { infusions }\end{array}$ & $\begin{array}{l}96.8 \%(30 / 31) \text { patients became negative after } 10.7 \\
\text { days; laboratory parameters (lymphocyte count, CRP, } \\
\text { procalcitonin level, IL-6, D-dimer level, PaO2/FiO2) } \\
\text { were significant improved compared to before applied } \\
\text { UCMSC therapy; } 96.8 \%(30 / 31) \text { Sars-CoV-2 clearance, } \\
87.1 \%(27 / 31) \text { discharged, } 12.9 \% \text { ( } 4 / 31) \text { death. }\end{array}$ & China & 33 \\
\hline 12 & 2020 & Case report & $\begin{array}{l}1 \text { patient }(65 \\
\text { year old) }\end{array}$ & NS & $\begin{array}{l}3 \text { infusions with } 5 \times 10^{7} \text { freshly } \\
\text { thawed UC-MSCs per infusion } \\
\text { with 3-day interval together with } \\
\text { thymosin alpha } 1 \text { and antibiotic } \\
\text { daily injection }\end{array}$ & $\begin{array}{l}\text { Most laboratory indexes and CT images showed remis- } \\
\text { sion of the inflammation sympton, patient was trans- } \\
\text { ferred out ICU and negative with virus } 4 \text { days later. }\end{array}$ & China & 34 \\
\hline
\end{tabular}




\begin{tabular}{|c|c|c|c|c|c|c|c|c|}
\hline No & Year & Kind of study & No of patients & $\begin{array}{l}\text { Follow- } \\
\text { up time }\end{array}$ & Interventions & Efficacy & Country & Ref \\
\hline 13 & 2020 & Case report & $\begin{array}{l}1 \text { patient (72 } \\
\text { year old) }\end{array}$ & NS & $\begin{array}{l}2 \text { doses of } 0.7 \times 10^{6} \mathrm{UC}-\mathrm{MSCs} / \mathrm{kg} \\
\text { for intravenous infusion, } 0.3 \times 10^{6} \\
\text { cells } / \mathrm{kg} \text { intratracheal with } 4 \text { units } \\
\text { of heparin, with } 5 \text { day interval }\end{array}$ & $\begin{array}{l}\text { After MSC transplantation, the need for inotropic } \\
\text { agents started to disappear, acidosis, electrolyte imbal- } \\
\text { ance and hypoxemia started to improve, CRP level re- } \\
\text { gressed; on day } 19 \text {, lung chest X-ray showed slight re- } \\
\text { gression of the ground-glass imaged infiltration in the } \\
\text { middle right lung periphery, and signigicant regression } \\
\text { in the low density infiltrations in the lower right ling } \\
\text { and lateral left lung. }\end{array}$ & Turkey & 35 \\
\hline 14 & 2021 & Case series & 11 patients & NS & $\begin{array}{l}4 \text { doses of } 0.5 \times 10^{6} \text { fresh UCM- } \\
\text { SCs/kg in } 100 \mathrm{~mL} \text { D5LR per dose } \\
\text { on day } 1,3,5 \text {, and } 7 \text { with duration } \\
40 \text { mins ( } 40 \text { drops } / \mathrm{min} \text { ) for } 9 \mathrm{pa}- \\
\text { tients; } 1 \text { patient with } 2 \text { doses (be- } \\
\text { cause UC-MSCs expired), } 1 \text { pa- } \\
\text { tient with } 1 \text { dose (developed ar- } \\
\text { rhythemia) }\end{array}$ & $\begin{array}{l}\text { 100\% patients CRP decreased; all patients with } 4 \text { doses } \\
\text { decreased cytokine levels (IL-6, IL10, IFN-gamma, } \\
\text { TNF-alpha). }\end{array}$ & Phillipir & 36 \\
\hline 15 & 2020 & Case report & $\begin{array}{l}1 \text { patient ( } 75 \\
\text { year) }\end{array}$ & 68 days & $\begin{array}{l}3 \text { doses of } 5 \times 10^{7} \text { cells per dose, } \\
\text { interval } 3 \text { days, suspended in } 100 \\
\mathrm{~mL} \text { saline, } 40 \text { drops } / \mathrm{min}\end{array}$ & $\begin{array}{l}\text { Symptons related to Covid-19 improved after } 30 \text { days } \\
\text { of MSC transplantation; after } 13 \text { days of transplanta- } \\
\text { tion, CT image showes that pneumonia infiltration was } \\
\text { suppressed; IL2, IL4, IL6, IL10, TNF-alpha and IFN- } \\
\text { gamma significant decreased. }\end{array}$ & China & 37 \\
\hline 16 & 2021 & Case series & 11 patients & 60 days & $\begin{array}{l}3 \text { doses of } 200 \times 10^{6} \text { freshly } \\
\text { thawed UC-MSCs/infusion for } \\
\text { each other day, IV, } 50 \text { drops } / \mathrm{min} \text {, } \\
\text { for } 30-45 \mathrm{~min} ; 6 \text { patients with } \\
\text { washed freshly thawed UC- } \\
\text { MSCs, } 5 \text { patients with fresh } \\
\text { placenta MSCs }\end{array}$ & $\begin{array}{l}6 / 11 \text { survived, } 5 \text { in } 6 \text { patients significantly improved } \\
\text { and discharged from ICU on } 2-7 \text { days after infu- } \\
\text { sions; proinflammatory cytokines (IL-9, TNF-alpha, } \\
\text { CRP) significant reduced; lung CT were available after } \\
\text { therapy in } 3 \text { survived cases; } 2 / 3 \text { patients showed signif- } \\
\text { icant resolution of opacities. }\end{array}$ & Iran & 38 \\
\hline
\end{tabular}

NS: Non-stated, UC-MSCs: Umbilical cord derived mesenchymal stem cells, CRP: C-reactive protein 


\section{ADVERSE EFFECTS AND SAFETY OF UC-MSC TRANSPLANTATION IN COVID-19 PATIENTS}

In 395 patients infused with UC-MSCs in 16 publications, 3 patients reported side effects, where 2 patients had side effects at the first infusion and 1 patient had side effects at the third infusion. 1 patient noted facial flushing within $4 \mathrm{~h}$ after UC-MSC infusion and was relieved within $24 \mathrm{~h} ; 1$ patient had transient fever that was no more than $38^{\circ} \mathrm{C}$ within $2 \mathrm{~h}$ after UC-MSC transplantation and was relieved within $24 \mathrm{~h}$; 1 patient reported hypoxemia that occurred 12 $\mathrm{h}$ after UC-MSC transplantation, although this effect was considered to be a progression of COVID19 , and the patient recovered after humidified highflow nasal cannula oxygen therapy ${ }^{28}$. Hashemian et al. (2021) reported that 2 (of a total 11) patients in their study developed shivering in the first infusion that did not develop further in the $2^{\text {nd }}$ and $3^{r d}$ infusions ${ }^{38}$. However, both patients were recorded in the group of placenta-derived MSCs, not in the UC-MSC group $^{38}$.

Feng et al. (2021) conducted an open-label randomized trial in 12 patients following hospital discharge for 3 months to evaluate UC-MSC transplantation's safety and showed that intravenous transplantation of UC-MSCs accelerated partial pulmonary function recovery and improved health-related quality of life (HRQL) without any side effects detected ${ }^{39}$. Similarly, Hashemian et al. (2021) followed-up 12 patients with UC-MSC transplantation for 60 days and found no allergic reactions or SAEs during this time ${ }^{38}$.

These results suggested that UC-MSC transplantation in COVID-19 patients is safe, and without severe side effects. Although these UC-MSC transplantation findings for COVID-19 patients are early and primary results, some published works that used UC-MSCs in other diseases supported the safety of UC-MSC transplantations over the longer term. In a study using UC-MSC transplantation for rheumatoid arthritis (RA), Wang et al. (2019) showed that UC-MSC treatment is safe after three years of UCMSC transplantation through routine blood analyses, liver and kidney function, and immunoglobulin examinations ${ }^{40}$. In another study, Wang et al. (2017) also demonstrated that UC-MSC infusions with two doses in systemic lupus erythematosus are safe with no changes in peripheral red/white blood cell count and platelet number after being followed-up for six years $^{41}$. The safety of high-dose UC-MSCs was evaluated in 2020 by Chin et al. The authors compared the safety and anti-inflammatory nature of UC-MSCs at two doses $\left(65\right.$ and $130 \times 10^{6}$ cells/infusion as low and high doses, respectively) in healthy volunteers, and all groups were followed up for 6 months. All subjects in both groups tolerated the doses well without any adverse reactions. After 6 months, subjects in the high-dose group displayed significantly higher anti-inflammatory markers and lower proinflammatory markers than subjects in the low-dose group ${ }^{42}$. In severe sepsis patients, He et al. (2018) showed that a single high dose of UC-MSCs $\left(3 \times 10^{6}\right.$ cells $\left./ \mathrm{kg}\right)$ is safe and well tolerated ${ }^{43}$.

\section{THERAPEUTIC EFFECTS OF UC-MSC TRANSPLANTATION IN COVID-19 PATIENTS}

All 16 published studies concluded that UC-MSC transplantation is beneficial in treating subjects with COVID-19 respiratory distress syndrome. Clinically, UC-MSC transplantation could significantly reduce the mortality ratio. The results from 4 RCT studies with a control (conventional treatment) showed that UC-MSC transplantation helped considerably reduce mortality ${ }^{5,31}$. For example, in the RCT study by Lei et al. (2021), there was a $0 \%(0 / 12)$ death rate, whereas in the control, there was a $10.34 \%(3 / 29)$ death rate ${ }^{5}$. In another RCT study, Dilogo et al. (2021) reported a survival rate of the UC-MSC transplantation group that was 2.5 times higher than in the control ${ }^{31}$. In a recent RCT study, Lanzoni et al. (2021) also showed that UCMSC transplantation significantly improved patient survival by $91 \%$ in the transplanted group whilst only displaying an improvement of $42 \%$ in the control $^{30}$.

The UC-MSC transplantation significantly reduced the time for recovery compared to the control. For example, Lei et al. (2021) showed that the time for recovery in the treatment group was 6 days compared to 12 days in the control ${ }^{5}$. Furthermore, Lanzoni and colleagues (2021) reported that the time for recovery was also reduced in the UC-MSC transplantation compared to the control ${ }^{30}$.

Lung inflammation was found to be significantly reduced in UC-MSC transplantation compared to a control according to lung imaging (CT or X-ray) and biochemical laboratory tests. Chest CT scanning showed that absorption of lung inflammation was faster in the treatment than control ${ }^{\mathbf{5 , 2 4}}$. After 28 days of treatment, solid component lesions were significantly different in MSC and placebo groups; there was a decrease in ground-glass lesions in the MSC vs. placebo group, but this difference was not statistically significant ${ }^{29}$. In some case reports, the UC- 


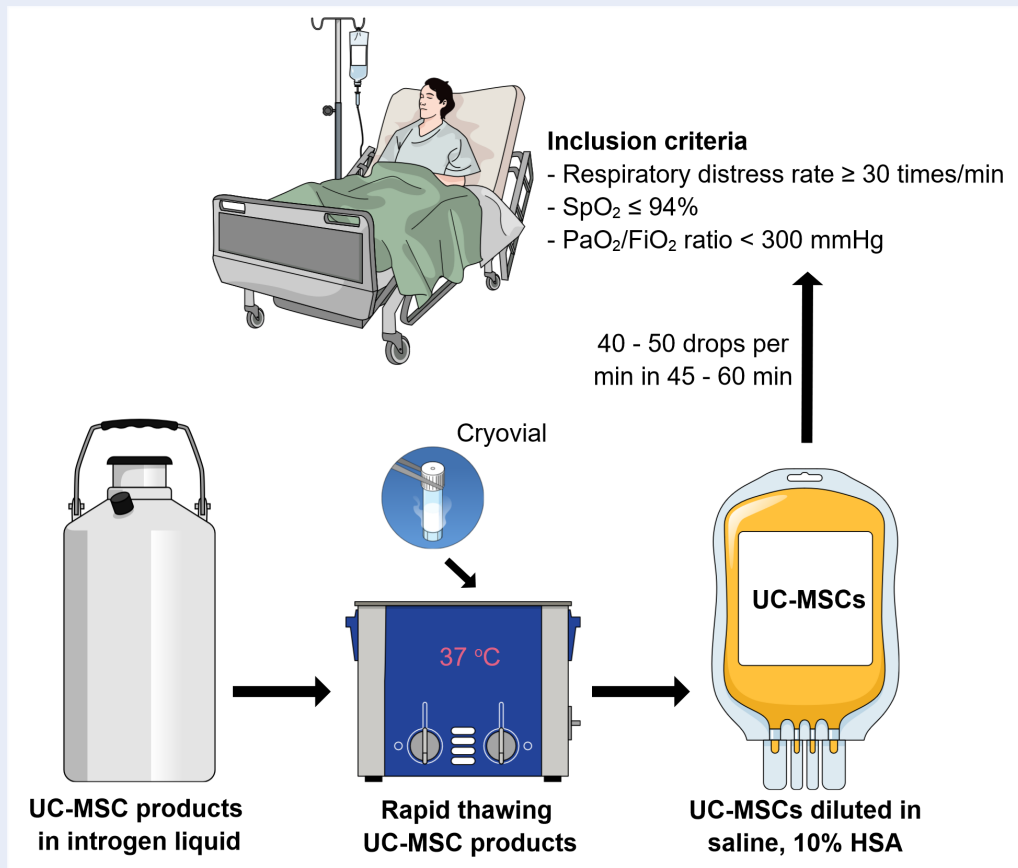

Figure 1: Suggested protocol for UC-MSC transplantation in Covid-19 treatment. UC-MSC off-the-shelf stem cell products are rapidly thawed in waterbath, then these samples are diluted in $50-100 \mathrm{~mL}$ of normal saline supplemented with $10 \% \mathrm{HSA}$ in $50-100 \mathrm{~mL}$. These products are intravenously infused to the patients with $40-$ 50 drops per min over $45-60 \mathrm{~min}$. https://doi.org/10.6084/m9.figshare.16727437.v1

MSC transplantation also improved lung inflammation based on lung CT images ${ }^{32,34,35,38}$. The laboratory tests showed that almost all patients treated with UC-MSC transplantation had decreased CRP, IL-6, and TNF- $\alpha^{5,26-28,31}$, and this reduction could be detected early in days $2-3$ post-transplantation [31, 40] or later at 7 - 14 days post-transplantation ${ }^{26,28}$. However, Wei et al. (2021) showed that although there were significant improvements in symptoms, the biomarkers of CRP, IL- 6 , and TNF- $\alpha$ were not significantly reduced after $1-3,5-8$, and $12-16$ days following UC-MSC infusion ${ }^{24}$ in a study of 12 patients.

\section{DOSES OF UC-MSCS, TREATMENT EFFICACY, AND ANTI-INFLAMMATORY ACTIVITY}

Through obtaining information from 16 publications that detail the application of UC-MSCs for COVID19, two methods are employed to determine the UCMSC dose for transplantation. Six publications used the total cell numbers per patient, with similar numbers for each study's patients, whereas ten publications determined the dose of UC-MSCs based on the patients' body weight. Based on the cell count per patient, the lowest dose was reported as $40^{29}$ and the highest $600^{38} \times 10^{6}$ cells/patient. In the case of a high dose, almost all studies shared cells into $2-3$ infusions with 3-day intervals. In a second approach, the cell dose was calculated based on body weight, with the lowest dose approximately $10^{6}$ cells $/ \mathrm{kg}$ of body weight ${ }^{24,31,33}$. Almost all studies used doses from $1-$ $2 \times 10^{6}$ cells $/ \mathrm{kg}$ with a single infusion. In some case reports, patients could receive $2-3$ infusions so that the total cells per patient did not exceed $6 \times 10^{6}$ cells $^{26,36}$. With these doses, all patients showed significantly improved clinical signs and reduced mortality. However, there is currently insufficient data to analyze the dose-dependent effects of UC-MSCs in COVID-19 patients. In a previous study, Chin et al. (2020) found that at a dose of $130 \times 10^{6}$ cells of UC-MSC per infusion, the anti-inflammatory effect was better than at a dose of $65 \times 10^{6}$ cells in healthy volunteers until six months post-transplantation ${ }^{42}$. From 16 of the most recent publications, one study discussed 12 patients treated with UC-MSCs; although the clinical observations were improved, anti-inflammatory biomarkers (CRP, IL-6, TNF- $\alpha$ ) were not significantly decreased 
after $1-3,5-8$, and $12-16$ days post-UC-MSC infusion, similar to the control (without UC-MSC infusion) ${ }^{\mathbf{2 4}}$. To explain this difference compared to other publications, Wei et al. (2021) found no apparent cytokine storm in transplanted patients. It seems that the UC-MSC transplantation in the late stage of a cytokine storm can be responsible for these subtle changes $^{24}$. The authors also suggested that UC-MSC transplantation in the early stage of a cytokine storm can effectively alter anti-inflammation markers ${ }^{24}$.

However, in our experience, the second reason for a non-significant change in anti-inflammatory biomarkers in transplanted patients is due to the low UC-MSC dose used in this study. An in vitro study of the immune modulation of UC-MSCs clearly showed that these cells' potency depends on the ratios of UCMSCs and immune cells ${ }^{17}$. Chin et al. (2020) confirmed this observation in healthy volunteers when comparing two doses (low and high $=1.0$ and $2.1 \mathrm{x}$ $10^{6}$ cells $/ \mathrm{kg}$, respectively) ${ }^{42}$. Therefore, depending on the desired effects of UC-MSCs in COVID-19 patients, such cells can be used with a suitable dose and for a particular stage of this disease. Furthermore, the physiological parameters were also used to evaluate the effects of UC-MSCs in the patients.

\section{FRESH VERSUS FRESHLY THAWED CELLS IN TREATMENT EFFICACY AND EXPLORING OFF-THE-SHELF UC-MSC PRODUCT USE FOR COVID-19 TREATMENT}

Both fresh and thawed UC-MSCs were utilized in the treatment of COVID-19. In 16 publications (included 6 case reports), 9 studies used fresh UC-MSCs prepared in the laboratory $5,24-26,28,32,33,36,4$ studies used freshly thawed cryopreserved UC-MSCs that had not been refreshed by in vitro culture before use $27,30,34,38$, and 1 study used UC-MSCs that had been shipped and maintained at $8-12{ }^{\circ} \mathrm{C}$ for less than $6 \mathrm{~h}$ before they were used ${ }^{38}$. Two studies did not provide information regarding whether their UC-MSCs were fresh or thawed ${ }^{35,37}$.

With the limitation of patients and studies, it is difficult to demonstrate and compare the efficacy of fresh or cool-kept and freshly thawed UC-MSCs with respect to COVID-19 treatment. There are controversial results in the literature about the potency of fresh versus freshly thawed MSCs. Immune modulation of thawed and fresh MSCs are comparable in vitro and in vivo in acute inflammatory diseases of septic animals ${ }^{44}$ in ischemic models ${ }^{45}$. At the same time, some previous publications have suggested that cryopreserved MSCs have impaired immunomodulation potency ${ }^{46,47}$. More interestingly, Chabot et al. (2017) demonstrated that freshly thawed and fresh UC-MSCs displayed comparable viability, functionality, and integrity ${ }^{48}$; however, if cryopreserved MSCs were left at RT for 2-10 min and then transferred to liquid nitrogen, they are functionally impaired and exhibit cellular damage despite being highly viable after thawing ${ }^{48}$. This impairment is correlated to a loss of adhesion and altered cell size ${ }^{49}$. Hence, the warming events and then re-cryopreservation cause the loss of adhesion and altered cell size of UC-MSCs resulting in functional impairment.

We noticed this information from a randomized, double-blind, placebo-controlled phase 2 trial by Shi et al. $(2021)^{29}$. However, the authors concluded that UC-MSC treatment is a safe and potentially effective therapeutic approach for COVID-19 patients with lung damage and suggested a phase 3 trial for this therapy. There are few differences in clinical and laboratory test findings between treatment versus control groups. Indeed, after 28 days, whole-lung lesion volume improved in the treatment group compared to the placebo with a p-value of 0.08 ; the proportions of solid component lesion volume were significantly reduced compared to the control with a p-value of 0.043 ; the 6-minute walking distance was longer in the MSC versus placebo group with a $\mathrm{p}$-value of 0.057 . Similarly, there were no significant differences in subsets of $\mathrm{CD} 4^{+} \mathrm{T}, \mathrm{CD}^{+} \mathrm{T}, \mathrm{B}$, and NK cells. Notably, plasma markers for inflammation (IL-6, IL-8, IFN- $\gamma$, IL-1Ra, IL-18, MCP-1, MIP-1 $\alpha$, and IP-10) also showed no significant difference between groups $0,6,10$, and 14 days after infusion ${ }^{29}$.

These findings appear to demonstrate that UC-MSC treatment is of a lower efficacy compared to in other publications. In our opinion, these unexpected results could be due to the MSC quality. Indeed, the cell dose was not low $\left(90 \times 10^{6}\right.$ cells shared between 3 infusion times on days 0,3 , and 6 ). MSC potency may have been reduced during shipments in cold conditions ( 8 $-12{ }^{\circ} \mathrm{C}$ ) by railway from the cell factory to the hospital for less than $6 \mathrm{~h}$ (as the authors stated). We do not have experimental evidence that the UC-MSC potency was reduced during cold storage. Nevertheless, Nikolaev et al. (2012), who analyzed bone marrowderived MSCs, showed that in cold storage $\left(2-8^{\circ} \mathrm{C}\right)$, BM-MSCs reduced the expression of CD29, CD44, CD105, and CD166. After $24 \mathrm{~h}$ in this condition, CD29 and CD166 were noticeably down-regulated, whereas CD105 and CD166 were negative, although these cells showed a high expression of CD29, CD44, 
CD105, and CD166 before storage ${ }^{50}$. In another study, Petrenko et al. (2019) stored BM-MSCs in some clinically relevant solutions (Plasma-Lyte 148 , HypoThermosol ${ }^{\circ}$ FRS, and Ringer's solution) at $4{ }^{\circ} \mathrm{C}$ and investigated the effects of cold storage on the viability, surface marker expression as well as their immune modulation potency. The authors showed a non-significant difference in surface markers for cold storage at 24, 48, and $72 \mathrm{~h}$ for CD105, CD90, CD73, CD34, CD45, CD19, CD14, and HLA-DR. However, the immune modulation potency was significantly reduced after $72 \mathrm{~h}$ of cold storage in all investigated media ${ }^{51}$. In Ringer's solution, the immune modulation capacity of storage BM-MSCs lost more than 50\% compared to fresh cells (as the control) ${ }^{51}$.

Freshly thawed UC-MSCs were used in 1 RCT study, 1 case series report, and 2 case reports to treat COVID19 patients with a total of 20 COVID-19 patients infused with freshly thawed UC-MSCs. The results from the RCT study showed that freshly thawed UCMSCs significantly reduced inflammatory cytokines compared to the control at day 6 and significantly improved patient survival (91\% in UC-MSC transplantation versus $42 \%$ in the control). The time to recovery was also reduced in transplanted patients compared to the control ${ }^{30}$. From this discussion, we believe that our proposal for use of off-the-shelf UCMSC products for COVID-19 treatment is a suitable approach ${ }^{14}$. However, further studies investigating the immune modulation potency of freshly thawed UC-MSCs for COVID-19 are essential to support this idea.

\section{UC-MSCS NOT ONLY TARGET CYTOKINE STORMS BUT ALSO TRIGGER TISSUE REGENERATION}

Lei et al. (2021) followed-up patients who had been discharged from hospital in both groups treated with UC-MSCs and standard therapy in a study over 3 months ${ }^{39}$. The effects of UC-MSC transplantation not only targeted cytokine storms that significantly reduced inflammation in COVID-19 patients ${ }^{5}$ but also accelerated partial pulmonary function recovery and improved HRQL ${ }^{39}$. Feng et al. (2021) examined liver, kidney, and pulmonary function, coagulation, tumor markers, and vision for all discharged patients after UC-MSC transplantation and standard therapy. Patients were also subjected to electrocardiography (ECG), tested with St. George's respiratory questionnaire (SGRQ), and had computed tomography (CT) imaging performed to assess lung changes. The results showed that blood routine index, CRP, procalcitonin, liver and kidney function, coagulation, ECG, tumor markers, and vision were almost within the normal ranges in both the UC-MSC transplantation group and control. However, the lung function recovered in the UC-MSC transplantation group compared to the control group. Both forced expiratory volumes in $1 \mathrm{~s}$ (FEV1) and FEV1/forced vital capacity (FEV1/FVC) ratios in the UC-MSC group were significantly higher than in the control group. SGRQ scores were clearly lower in the UC-MSC vs. control group.

These preliminary results suggest that UC-MSC transplantation is not essential for attenuating cytokine storms in COVID-19 patients but also for accelerating tissue regeneration. Indeed, Wei et al. (2021) also found that transplantation of UC-MSCs in COVID-19 patients did not reduce the levels of CRP, IL-6, and TNF- $\alpha$. Still, the oxygenation index was significantly improved after $12-16$ days. These results confirmed the roles of UC-MSCs in pulmonary recovery again ${ }^{24}$.

\section{SUGGESTED UC-MSC PROTOCOL FOR COVID-19 TREATMENT}

\section{Inclusion and exclusion criteria}

Inclusion criteria: patients currently hospitalized with respiratory distress rate $\geq 30$ times $/ \mathrm{min}, \mathrm{SpO}_{2}$ $\leq 94 \%$ at room air, $\mathrm{PaO}_{2} / \mathrm{FiO}_{2}$ ratio $<300 \mathrm{mmHg}$, willing and able to provide written informed consent. Exclusion criteria: patients with $\mathrm{PaO}_{2} / \mathrm{FiO}_{2} \geq 300$ $\mathrm{mmHg}$ at the time of enrollment, infused with MSCs, history of pulmonary hypertension (WHO class III/IV), history of left arterial hypertension, pregnant or lactating, present active malignancy, moderate or severe liver disease.

\section{UC-MSC products}

As suggested in the previously published article ${ }^{\mathbf{1 4}}$, cryopreserved UC-MSCs (off-the-shelf stem cells) should be used for COVID-19 treatment. Indeed, such off-the-shelf UC-MSC products provide multiple benefits: (1) Ready-to-use products for use in all emergency cases, particularly for COVID-19. If UC-MSC transplantation is used to suppress cytokine storms in COVID-19 patients, ready-to-use products such as off-the-shelf UC-MSC cells are essential so that medical doctors can choose a suitable time for transplantation. (2) Off-the-shelf UC-MSC products are produced at a large scale with strictly controlled quality, therefore their cost is significantly reduced as opposed to a freshly prepared batch for each case. In particular, the strictly controlled quality for each batch improves the treatment's stability. 


\section{Infusion protocol}

The UC-MSC products should be used as freshly thawed samples without re-freezing. Depending on the components of cryopreservation media, the samples can be washed to remove the cryopreservation media, or the freshly thawed samples can directly be used without the washing step. The UC-MSCs should be re-suspended or diluted in $50-100 \mathrm{~mL}$ of normal saline supplemented with 10\% HSA and anticoagulation (heparin or citrate dextrose). The cell suspension is intravenously infused into the patient through a blood filter tubing set with a pore size of $170 \mu \mathrm{m}$, with 40 - 50 drops per min over 45 - 60 min (Figure 1).

\section{Monitoring and efficacy evaluation}

Patients will be monitored for COVID-19 symptoms, lung recovery, and inflammation response before and after UC-MSC transplantation. $\mathrm{SpO}_{2}$ and $\mathrm{PaO}_{2} / \mathrm{FiO}_{2}$ should be used as indicators for respiratory recovery. CT lung images can be used to evaluate lung inflammation, and some biomarkers, such as CRP, IL-6, TNF- $\alpha$, can be utilized to monitor the inflammation response. $\mathrm{SpO}_{2}$ and $\mathrm{PaO}_{2} / \mathrm{FiO}_{2}$ should be observed every day, whereas biomarkers should be evaluated every two days for 7 - 14 days. For lung recovery and tissue regeneration after hospital discharge, patients should be evaluated with respect to their respiratory, liver, kidney, and vision functions $30-60$ days after discharge.

\section{CONCLUSION}

COVID-19 has caused a rapidly evolving global pandemic with effects on hundreds of millions of people. Therefore, besides the established standard therapy and vaccination, UC-MSC transplantation should be considered as an adjuvant therapy for standard treatment to significantly reduce mortality and accelerate pulmonary regeneration. Furthermore, with largescale UC-MSC manufacturing in GMP-compliant conditions, off-the-shelf UC-MSC products can be used as freshly thawed with or without washing to remove the cryopreserved media. Because data for the clinical application of freshly thawed UC-MSC transplantation for COVID-19 is limited, additional wellcontrolled clinical trials with an increased number of patients should be performed. I believe that with the current evidence, UC-MSC transplantation is a highly suitable option for medical doctors to use for COVID19 treatment.

\section{ABBREVIATIONS}

BM: Bone marrow
Covid-19: Coronavirus disease 2019

GMP: Good manufacture practice

HRQL: Health-related quality of life

MSC: Mesenchymal stem cell

SpO2: Blood oxygen saturation

UC-MSC: Umbilical cord derived mesenchymal stem cell

\section{ACKNOWLEDGMENTS}

None.

\section{AUTHOR'S CONTRIBUTIONS}

Authors equally contributed to this work. All authors read and approved the final manuscript.

\section{FUNDING}

None.

\section{AVAILABILITY OF DATA AND MATERIALS}

Not applicable.

\section{ETHICS APPROVAL AND CONSENT TO PARTICIPATE}

Not applicable.

\section{CONSENT FOR PUBLICATION}

Not applicable.

\section{COMPETING INTERESTS}

The authors declare that they have no competing interests.

\section{REFERENCES}

1. COVID-19 Dashboard by the Center for Systems Science and Engineering (CSSE) at Johns Hopkins University (JHU) https:// coronavirus.jhu.edu/map.html.

2. Singhal T. A Review of Coronavirus Disease-2019 (COVID19). The Indian Journal of Pediatrics. 2020;87(4):281-6. PMID: 32166607. Available from: 10.1007/s12098-020-03263-6.

3. Yuki K, Fujiogi M, Koutsogiannaki S. COVID-19 pathophysiology: A review. Clinical Immunology. 2020;215:108427108427. PMID: 32325252 . Available from: 10.1016/j.clim.2020. 108427.

4. Pollard CA, Morran MP, Nestor-Kalinoski AL. The COVID-19 pandemic: a global health crisis. Physiological Genomics. 2020;52(11):549-57. PMID: 32991251. Available from: 10. 1152/physiolgenomics.00089.2020.

5. Shu L, Niu C, Li R, Huang T, Wang Y, Huang M, et al. Treatment of severe COVID-19 with human umbilical cord mesenchymal stem cells. Stem Cell Research and Therapy. 2020;11:361. PMID: 32811531. Available from: 10.1186/s13287-020-018755.

6. Xu X, Ong YK, Wang Y. Role of adjunctive treatment strategies in COVID-19 and a review of international and national clinical guidelines. Military Medical Research. 2020;7(1):22. PMID: 32370766. Available from: 10.1186/s40779-020-00251-x. 
7. Pau AK, Aberg J, Baker J, Belperio PS, Coopersmith C, Crew $P$, et al. Convalescent Plasma for the Treatment of COVID19: Perspectives of the National Institutes of Health COVID19 Treatment Guidelines Panel. Annals of internal medicine. 2021;174(1):93-5. PMID: 32976026. Available from: 10.7326/ M20-6448.

8. Budhathoki P, Shrestha DB, Rawal E, Khadka S. Corticosteroids in COVID-19: Is it Rational? A Systematic Review and MetaAnalysis. SN comprehensive clinical medicine. 2020;2(12):121. PMID: 33103063 . Available from: 10.1007/s42399-02000515-6.

9. Lentz S, Roginski MA, Montrief T, Ramzy M, Gottlieb $M$, Long B. Initial emergency department mechanical ventilation strategies for COVID-19 hypoxemic respiratory failure and ARDS. The American Journal of Emergency Medicine. 2020;38(10):2194-202. PMID: 33071092. Available from: 10.1016/j.ajem.2020.06.082.

10. Petrone P, Brathwaite CE, Joseph DK. Prone ventilation as treatment of acute respiratory distress syndrome related to COVID-19. European Journal of Trauma and Emergency Surgery. 2021;47(4):1017-22. PMID: 33201268. Available from: 10.1007/s00068-020-01542-7.

11. Leng Z, Zhu R, Hou W, Feng Y, Yang Y, Han Q, et al. Transplantation of ACE2-mesenchymal stem cells improves the outcome of patients with COVID-19 pneumonia. Aging and disease. 2020;11(2):216-28. PMID: 32257537. Available from: 10.14336/AD.2020.0228.

12. Reicin C, McMahon E, Chung C. Stem cell therapy regulation in Canada: implications of the prochymal approval. Westlaw Journal Pharmaceutical. 2012;28(8):1-4.

13. Rattue P. Prochymal-first stem cell drug approved. Medical News Today, 2012. 22.

14. Pham PV, Vu NB. Off-the-shelf mesenchymal stem cells from human umbilical cord tissue can significantly improve symptoms in COVID-19 patients: an analysis of evidential relations. World Journal of Stem Cells. 2020;12(8):721-30. PMID: 32952854. Available from: 10.4252/wjsc.v12.i8.721.

15. Kim JH, Jo CH, Kim HR, Hwang Yl. Comparison of Immunological Characteristics of Mesenchymal Stem Cells from the Periodontal Ligament, Umbilical Cord, and Adipose Tissue. Stem Cells International. 2018;2018:8429042. PMID: 29760736. Available from: 10.1155/2018/8429042.

16. Li J, Xu SQ, Zhao YM, Yu S, Ge LH, Xu BH. Comparison of the biological characteristics of human mesenchymal stem cells derived from exfoliated deciduous teeth, bone marrow, gingival tissue, and umbilical cord. Molecular Medicine Reports. 2018;18(6):4969-77. PMID: 30272340. Available from: 10.3892/mmr.2018.9501.

17. Pham PV, Bich NV, Phan NK. Umbilical cord-derived stem cells (Modulatist TM) show strong immunomodulation capacity compared to adipose tissue-derived or bone marrow-derived mesenchymal stem cells. Biomedical Research and Therapy. 2016;3(6):1-10. Available from: 10.7603/s40730-016-0029-1.

18. Mattar P, Bieback K. Comparing the Immunomodulatory Properties of Bone Marrow, Adipose Tissue, and BirthAssociated Tissue Mesenchymal Stromal Cells. Frontiers in immunology. 2015;6(560):560. PMID: 26579133. Available from: 10.3389/fimmu.2015.00560.

19. Wang $\mathrm{Q}$, Yang $\mathrm{Q}$, Wang $\mathrm{Z}$, Tong $\mathrm{H}, \mathrm{Ma}$ L, Zhang Y. Comparative analysis of human mesenchymal stem cells from fetalbone marrow, adipose tissue, and Warton's jelly as sources of cell immunomodulatory therapy. Hum Vaccin Immunother. 2016;12(1):85-96. PMID: 26186552. Available from: 10.1080/ 21645515.2015.1030549.

20. Bich PLT, Thi HN, Chau HDN, Van TP, Do Q, Khac HD. Allogeneic umbilical cord-derived mesenchymal stem cell transplantation for treating chronic obstructive pulmonary disease: a pilot clinical study. Stem Cell Res Ther. 2020;11(1):60. PMID: 32054512. Available from: 10.1186/s13287-020-1583-4.

21. Laroye C, Gibot S, Huselstein C, Bensoussan D. Mesenchymal stromal cells for sepsis and septic shock: lessons for treat- ment of COVID-19. Stem Cells Transl Med. 2020;9(12):148894. PMID: 32808462. Available from: 10.1002/sctm.20-0239.

22. Byrnes D, Masterson CH, Artigas A, Laffey JG. Mesenchymal Stem/Stromal Cells Therapy for Sepsis and Acute Respiratory Distress Syndrome. Semin Respir Crit Care Med. 2021;42(1):20-39. PMID: 32767301. Available from: 10.1055/ s- 0040-1713422.

23. Khosrojerdi A, Soudi S, Hosseini AZ, Eshghi F, Shafiee $A$, Hashemi SM. Immunomodulatory and Therapeutic Effects of Mesenchymal Stem Cells on Organ Dysfunction in Sepsis. Shock. 2021;55(4):423-40. PMID: 32826813. Available from: 10.1097/SHK.0000000000001644.

24. Wei F, Kong D, Li T, Li A, Tan Y, Fang J, et al. Efficacy and safety of umbilical cord mesenchymal stem cells for the treatment of patients with COVID-19. Clinics (Sao Paulo). 2021;76:e2604 PMID: 34008772. Available from: 10.6061/clinics/2021/e2604.

25. Ercelen NO, Pekkoc-Uyanik KC, Alpaydin N, Gulay GR, Simsek $M$. Clinical experience on umbilical cord mesenchymal stem cell treatment in 210 severe and critical COVID-19 cases in Turkey. Stem Cell Rev Rep. 2021;p. Online ahead of print. Available from: 10.1007/s12015-021-10214-x.

26. Zhang Q, Huang K, Lv J, Fang X, He J, Lv A. Case Report: Human Umbilical Cord Mesenchymal Stem Cells as a Therapeutic Intervention for a Critically III COVID-19 Patient. Front Med (Lausanne). 2021;8(943):691329. PMID: 34307417. Available from: 10.3389/fmed.2021.691329.

27. Ciccocioppo R, Gibellini D, Astori G, Bernardi M, Bozza A, Chieregato $\mathrm{K}$. The immune modulatory effects of umbilical cord-derived mesenchymal stromal cells in severe COVID19 pneumonia. Stem Cell Res Ther. 2021;12(1):316. PMID: 34078447. Available from: 10.1186/s13287-021-02376-9.

28. Meng F, Xu R, Wang S, Xu Z, Zhang C, Li Y. Human umbilical cord-derived mesenchymal stem cell therapy in patients with COVID-19: a phase 1 clinical trial. Signal Transduct Target Ther. 2020;5(1):172. PMID: 32855385. Available from: 10.1038/s41392-020-00286-5.

29. Shi L, Huang $H$, Lu X, Yan X, Jiang $X$, Xu R. Effect of human umbilical cord-derived mesenchymal stem cells on lung damage in severe COVID-19 patients: a randomized, doubleblind, placebo-controlled phase 2 trial. Signal Transduct Target Ther. 2021;6(1):58. PMID: 33568628. Available from: 10.1038/s41392-021-00488-5.

30. Lanzoni G, Linetsky E, Correa D, Cayetano SM, Alvarez RA, Kouroupis D. Umbilical cord mesenchymal stem cells for COVID-19 acute respiratory distress syndrome: A doubleblind, phase $1 / 2 a$, randomized controlled trial. Stem Cells Transl Med. 2021;10(5):660-73. PMID: 33400390. Available from: $10.1002 / \mathrm{sctm} .20-0472$.

31. Dilogo IH, Aditianingsih D, Sugiarto A, Burhan E, Damayanti T, Sitompul PA. Umbilical cord mesenchymal stromal cells as critical COVID-19 adjuvant therapy: A randomized controlled trial. Stem Cells Transl Med. 2021;10(9):1279-87. PMID: 34102020. Available from: 10.1002/sctm.21-0046.

32. Senegaglia AC, Rebelatto CL, Franck CL, Lima JS, Boldrini-Leite LM, Daga DR. Combined Use of Tocilizumab and Mesenchymal Stromal Cells in the Treatment of Severe Covid-19: case Report. Cell Transplant. 2021;30:9636897211021008. PMID: 34074163. Available from: 10.1177/09636897211021008.

33. Guo Z, Chen Y, Luo X, He X, Zhang Y, Wang J. Administration of umbilical cord mesenchymal stem cells in patients with severe COVID-19 pneumonia. Crit Care. 2020;24(1):420. PMID: 32653043. Available from: 10.1186/s13054-020-03142-8.

34. Liang B, Chen J, Li T, Wu H, Yang W, Li Y. Clinical remission of a critically ill COVID-19 patient treated by human umbilical cord mesenchymal stem cells: A case report. Medicine (Baltimore). 2020;99(31):e21429. PMID: 32756149. Available from: 10.1097/MD.0000000000021429.

35. Zengin R, Beyaz O, Koc ES, Akinci IO, Kocagoz S, Sagcan G. Mesenchymal stem cell treatment in a critically ill COVID-19 patient: a case report. Stem Cell Investig. 2020;7:17. PMID: 33110915. Available from: 10.21037/sci-2020-024. 
36. Vera MJD, Buensalido MJ, Francisco JJ, Bello JA, Olavere A, Calavera A, et al. Use of Umbilical Cord Mesencymal Stem Cells in the Treatment of Severe COVID-19 Pneumonia. Journal of Embryology \& Stem Cell Research. 2021;5(1):000146. Available from: $10.23880 /$ jes- 16000146 .

37. Chen H, Zhang L, He Z, Wang D, Liu L, Zhang W, et al. Systemic administration of human umbilical cord-derived mesenchymal stem cells effectively ameliorates the outcomes of a critically ill elderly patient with COVID-19 with multiple comorbidities: A case report. World Acad Sci J. 2020;2(6):29. Available from: 10.3892/wasj.2020.70.

38. Hashemian SR, Aliannejad R, Zarrabi M, Soleimani M, Vosough $M$, Hosseini SE. Mesenchymal stem cells derived from perinatal tissues for treatment of critically ill COVID-19-induced ARDS patients: a case series. Stem Cell Res Ther. 2021;12(1):91. PMID: 33514427. Available from: 10.1186/s13287-021-021654.

39. Feng $G$, Shi L, Huang $T$, Ji N, Zheng $Y$, Lin $H$, et al. Human umbilical cord mesenchymal stromal cell treatment of severe COVID-19 patients: a three-month follow-up study following hospital discharge. Stem Cells Dev. 2021;30(15):773-81. PMID: 34044609. Available from: 10.1089/scd.2021.0015.

40. Wang L, Huang S, Li S, Li M, Shi J, Bai W. Efficacy and Safety of Umbilical Cord Mesenchymal Stem Cell Therapy for Rheumatoid Arthritis Patients: A Prospective Phase I/II Study. Drug Des Devel Ther. 2019;13:4331-40. PMID: 31908418. Available from: 10.2147/DDDT.S225613.

41. Wang D, Niu L, Feng X, Yuan X, Zhao S, Zhang H. Long-term safety of umbilical cord mesenchymal stem cells transplantation for systemic lupus erythematosus: a 6-year follow-up study. Clin Exp Med. 2017;17(3):333-40. PMID: 27270729. Available from: 10.1007/s10238-016-0427-0.

42. Chin SP, Mohd-Shahrizal MY, Liyana MZ, Then KY, Cheong SK, Yong KW. High Dose of Intravenous Allogeneic Umbilical Cord-Derived Mesenchymal Stem Cells (CLV-100) Infusion Displays Better Immunomodulatory Effect among Healthy Volunteers: A Phase 1 Clinical Study. Stem Cells Int 2020;2020:8877003-8877003. PMID: 33061992. Available from: $10.1155 / 2020 / 8877003$.

43. He X, Ai S, Guo W, Yang Y, Wang Z, Jiang D. Umbilical cordderived mesenchymal stem (stromal) cells for treatment of severe sepsis: aphase 1 clinical trial. Transl Res. 2018;199:52-61.
PMID: 30044959. Available from: 10.1016/j.trsl.2018.04.006.

44. Tan Y, Salkhordeh M, Wang JP, McRae A, Souza-Moreira L, Mclntyre L. Thawed Mesenchymal Stem Cell Product Shows Comparable Immunomodulatory Potency to Cultured Cells In Vitro and in Polymicrobial Septic Animals. Sci Rep. 2019;9(1):18078. PMID: 31792313. Available from: 10.1038/ s41598-019-54462-x.

45. Gramlich OW, Burand AJ, Brown AJ, Deutsch RJ, Kuehn MH, Ankrum JA. Cryopreserved Mesenchymal Stromal Cells Maintain Potency in a Retinal Ischemia/Reperfusion Injury Model: toward an off-the-shelf Therapy. Sci Rep. 2016;6(1):2646326463. PMID: 27212469. Available from: 10.1038/srep26463.

46. François M, Copland IB, Yuan S, Romieu-Mourez R, Waller EK, Galipeau J. Cryopreserved mesenchymal stromal cells display impaired immunosuppressive properties as a result of heatshock response and impaired interferon- $\gamma$ licensing. Cytotherapy. 2012;14(2):147-52. PMID: 22029655. Available from: $10.3109 / 14653249.2011 .623691$.

47. Moll G, Alm JJ, Davies LC, von Bahr L, Heldring N, StenbeckFunke L. Do cryopreserved mesenchymal stromal cells display impaired immunomodulatory and therapeutic properties? Stem Cells. 2014;32(9):2430-42. PMID: 24805247. Available from: $10.1002 /$ stem.1729.

48. Chabot D, Tremblay T, Paré I, Bazin R, Loubaki L. Transient warming events occurring after freezing impairs umbilical cord-derived mesenchymal stromal cells functionality. Cytotherapy. 2017;19(8):978-89. PMID: 28606762. Available from: $10.1016 /$ j.jcyt.2017.04.005.

49. Chabot D, Lewin A, Loubaki L, Bazin R. Functional impairment of MSC induced by transient warming events: correlation with loss of adhesion and altered cell size. Cytotherapy. 2018;20(8):990-1000. PMID: 30093326. Available from: 10.1016/j.jcyt.2018.05.010.

50. Nikolaev NI, Liu Y, Hussein H, Williams DJ. The sensitivity of human mesenchymal stem cells to vibration and cold storage conditions representative of cold transportation. J R Soc Interface. 2012;9(75):2503-15. PMID: 22628214. Available from: 10.1098/rsif.2012.0271.

51. Petrenko Y, Chudickova M, Vackova I, Groh T, Kosnarova E, Cejkova J. Clinically Relevant Solution for the Hypothermic Storage and Transportation of Human Multipotent Mesenchymal Stromal Cells. Stem Cells Int. 2019:2019:5909524-5909524. PMID: 30805009. Available from: 10.1155/2019/5909524. 
Ready to submit your manuscript? Choose Biomedpress and benefit from:

- Fast, convenient online submission

- Through peer-review by experienced researchers

- Rapid publication on acceptance

- Free of charge (without publication fees)

Learn more http://www.biomedpress.org/journals/

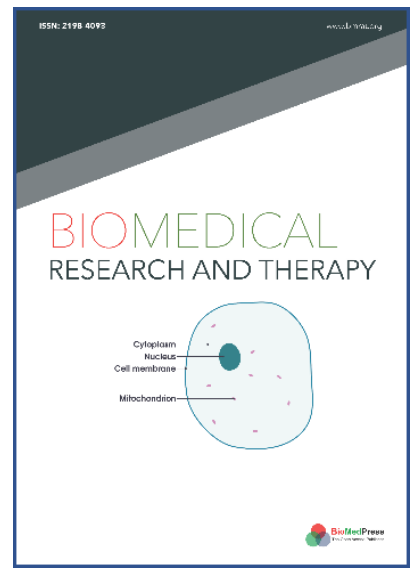

\title{
Biomedical Research and Therapy
}

Indexed: Web of Science (ESCl), Embase, Google Scholar

Journal Citation Indicator (2020): 0.16

Acceptance Rate (2020): 54.32\%

Article Publishing Charge: Free

Submission to first editorial decision: 27 days

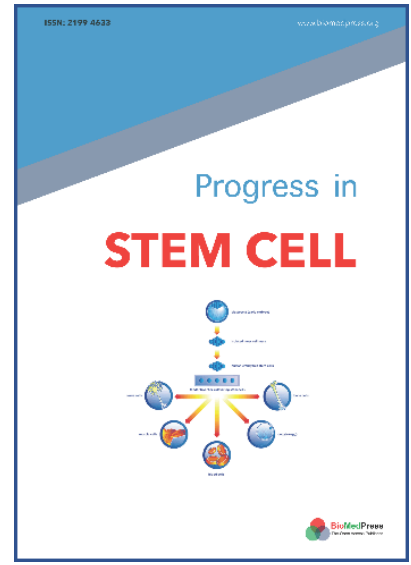

\section{Progress in Stem Cell}

Indexed: Embase, Google Scholar

Acceptance Rate (2020): 78.19\%

Article Publishing Charge: Free

Submission to first editorial decision: 19 days

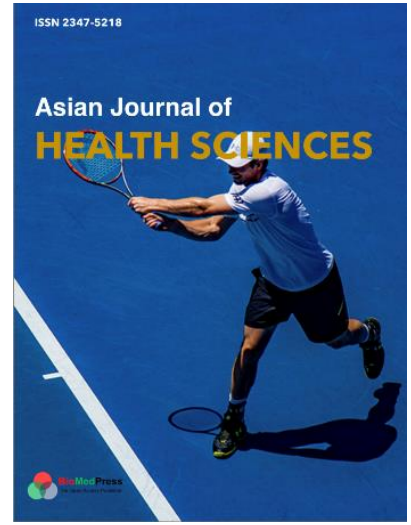

\author{
Asian Journal of Health Sciences \\ Indexed: Google Scholar \\ Acceptance Rate (2020): 72.89\% \\ Article Publishing Charge: Free \\ Submission to first editorial decision: 16.5 days
}

